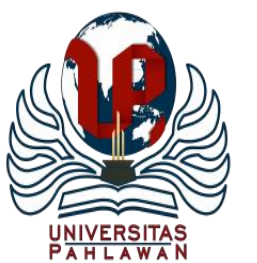

Jurnal Basicedu Volume 3 Nomor 2 Tahun 2019 Halaman 515-523

JURNAL BASICEDU

Research \& Learning in Elementary Education

https://jbasic.org/index.php/basicedu

\title{
PENANAMAN PENDIDIKAN KARAKTER ANAK DALAM STUKTUR SOSIAL KELUARGA DESA DI YOGYAKARTA
}

\author{
Ahmad Shofiyuddin Ichsan ${ }^{1}$ dan Samsudin ${ }^{2}$ \\ Institut Ilmu Al Qur'an An Nur Yogyakarta ${ }^{1,2}$ \\ E-mail: $\underline{\text { ahmad.shofiyuddin.ichsan@gmail.com }{ }^{1} \text {, seam.iiq.annur@gmail.com }{ }^{2}}$
}

\begin{abstract}
Abstrak
Penelitian ini bertujuan untuk mengungkapkan tentang struktur sosial keluarga desa di Yogyakarta yang berimplikasi pada penanaman pendidikan karakter anak dan mencoba menguraikan bagaimana pendekatan sosiologi (struktur fungsional) mampu memberikan sumbangsih keilmuan terhadap dinamika keluarga desa di Yogyakarta dalam konteks tersebut. Penelitian ini adalah penelitian kualitatif dengan jenis studi kasus di Kecamatan Piyungan Bantul Yogyakarta. Hasil penelitian menunjukkan bahwa anak dalam keluarga desa di Yogyakarta sejak dini telah diberikan pendidikan njawani, yakni pendidikan yang tidak hanya memahami bahasa Jawa, tetapi juga harus menjalankan etika, budaya, dan agama yang telah dilestarikan dalam masyarakat Jawa. Struktur sosial mampu memberi ruang dalam menanamkan pendidikan karakter pada anak. Untuk itu, diperlukan pemahaman secara utuh dengan menyadari dua aspek penting dalam melihat perubahan keluarga desa di Yogyakarta, yakni aspek struktural dan aspek fungsional.
\end{abstract}

Kata kunci: Pendidikan Karakter, Struktur Sosial, Keluarga Desa

\begin{abstract}
This study aims to reveal the social structure of village families in Yogyakarta that have implications for the cultivation of character education toward the children and it tries to explain how the sociological approach (functional structure theory) is able to contribute to the village family dynamics in Yogyakarta in that context. This research is a qualitative research with a type of case study in Piyungan Bantul Yogyakarta. The results of the study show that children in the village family in Yogyakarta have been given education from the beginning, namely education which not only understood Javanese, but also has to carry out ethics, culture, and religion that had been preserved in Javanese society. Social structure is able to provide space in instilling character education in children. For this reason, full understanding is needed by realizing two important aspects in looking at changes in village families in Yogyakarta, namely structural and functional aspects.
\end{abstract}

Keywords: Character Education, Social Structure, Village Family

@ Jurnal Basicedu Prodi PGSD FIP UPTT 2019

Corresponding author :

Address :

Email : ahmad.shofiyuddin.ichsan@gmail.com

ISSN 2580-3735 (Media Cetak)

Phone ISSN 2580-1147 (Media Online) 


\section{PENDAHULUAN}

Dalam konteks kajian antropologi, para ilmuwan mencoba menguraikan makna masyarakat sebagai kelompok yang hidup menetap dan saling bekerjasama satu sama lain sehingga mereka memiliki pengorganisasian dalam diri mereka sendiri. Begitu pula dalam kajian sosiologi, masyarakat dianggap sebagai kelompok manusia yang saling berhubungan sosial, baik mulai dari hubungan kelompok kecil maupun kelompok yang lebih besar. Kelompok kecil sebagaimana hubungan dengan keluarga, sedangkan kelompok besar seperti hubungan mereka dengan masyarakat desa, kota, bangsa, dan seterusnya. Hubungan sosial antara mereka inilah menjadikan diri mereka antara satu dengan yang saling mengkontrol.

Adanya sosial kontrol ini akan mengatur kehidupan masyarakat secara total. Dalam artian, semua kegiatan dan tindakan masyarakat telah diatur oleh mereka sendiri. Sehingga banyak yang menganggap bahwa sosial kontrol disebut juga dengan pengawas sosial. Pengawas sosial di sini meliputi sistem ilmu pengetahuan, ilmu teknik empiris yang digunakan dalam keseharian masyarakat dalam mengelola lingkungan sekitar, dan pengetahuan non empiris yang mengatur sikap dan tingkah polah, seperti etika, moralitas, ritual keagamaan, mitologi, dan seterusnya. (Beni Ahmad, 2012: 137-140). Maka adanya sosial kontrol ini pola berpikir masyarakat aan terbentuk sehingga sehingga dalam akan mempengaruhi sikap kesehariannya.

Bentukan sikap akibat adanya pola berpikir tersebut memberikan kecenderungan untuk berbuat atau tidak terhadap manusia, benda atau keadaan yang mengelilingi. Seseorang yang pola berpikirnya religius akan memiliki sikap tertentu terhadap semua aktifitasnya. Ia akan memperhatikan kepuasan batin dalam mengerjakan sesuatu. Begitu juga seseorang yang memiliki sikap materialistik akan bersikap sesuai kepentingan pekerjaan yang menghasilkan materi. Kedua hal tersebut menjadi wajar karena orientasi hasrat manusia pada dasarnya ada dua, yakni 1). Keinginan menjadi satu dengan manusia lain di sekelilingnya, dan 2). Keinginan untuk menjadi satu dengan suasana alam di sekitarnya. Sehingga kedua hasrat manusia tersebut dengan sendiri akan mengkonstruksi sikap individualnya.

Sikap tersebut lazimnya membentuk perilaku tertentu, yang kemudian menjadi pola perilaku apabila berlangsung secara sinambung. Jika pola perilaku tertentu sudah membudaya, maka gejala itu menjadi patokan perilaku yang pantas baginya. Patokan perilaku yang pantas tersebut biasanya disebut norma. Perangkat normanorma tertentu yang terdiri dari kaidah-kaidah kepercayaan, kesusilaan, kesopanan dan hukum, kemudian menjadi patokan dalam interaksi sosial. (Soerjono Soekanto, 2005).

Dalam interaksi sosial, keluarga menjadi sangat urgen dalam membentuk sikap seseorang, karena keluarga merupakan lembaga sosial pertama dan dasar dari semua lembaga-lembaga sosial lainnya. Di masyarakat manapun di dunia, keluarga merupakan kebutuhan manusia yang universal dan menjadi pusat terpenting dari kegiatan dalam kehidupan individu. Keluarga dapat digolongkan ke dalam kelompok penting, selain karena para anggotanya saling mengadakan kontak langsung juga karena adanya keintiman dari para anggota di dalamnya. Banyak penelitian menyebutkan bahwa karakter diri anak terbentuk dan memiliki identitas tertentu salah satunya adalah pengaruh kuat dari keluarganya. Dalam keluarga Jawa, misalnya, untuk membentuk identitas anak, orang tua di Jawa menanamkan pendidikan interaksi sosial sejak dini mungkin, melalui bahasa lisan sampai dengan bahasa tubuh. Maka tidak jarang bahwa kemampuan anak dalam 
berinteraksi sosial masyarakat Jawa sudah terbentuk.

Yogyakarta bagian dari masyarakat Jawa juga memiliki simbol menarik dalam berinteraksi sosial. Kita bisa menyaksikan kehidupan desa di Yogyakarta, bagaimana keluarga menanamkan pendidikan karakter kepada anak-anaknya, salah satunya pengajaran unggah-ungguh kepada seseorang yang lebih tua darinya. Dalam pengajaran itu, anak dididik bersikap lebih sopan kepada orang lain, khususnya orang tua. Ketika bertemu dengan orang yang lebih tua umurnya, anak harus menyapa dengan sopan ketika berjalan melewatinya. Anak juga harus merendahkan intonasi suaranya ketika diajak berbicara. Tidak hanya itu, senyuman hangat disertai bahasa tubuh khas pedesaan Yogyakarta juga harus dilakukannya. Penanaman pendidikan dari akibat adanya struktur sosial menjadikan keluarga desa di Yogyakarta sampai saat ini masih dilestarikan dengan baik.

Maka dari itu, disini peneliti ingin mengkaji bagaimana memahami struktur sosial keluarga desa di Yogyakarta yang berimplikasi pada penanaman pendidikan karakter anak. Tidak hanya itu, tulisan ini juga mencoba menguraikan bagaimana pendekatan sosiologi mampu memberikan sumbangsih keilmuan terhadap dinamika keluarga desa di Yogyakarta dalam konteks tersebut.

Sebelum dijelaskan lebih lanjut, peneliti akan menguraikan teori yang dijadikan sebagai alat analisis dari penelitian ini, yakni pendidikan karakter dan teori struktur fungsional dalam ilmu sosiologi. Menurut Kemendiknas, setidaknya terdapat 18 nilai karakter yang harus ditanamkan kepada anak sejak dini, yakni religius, jujur, toleransi, disiplin, kerja keras, kreatif, mandiri, demokratis, rasa ingin tau, semangat Kebangsaan, cinta tanah air, menghargai prestasi, bersahabat/komunikatif, cinta damai, gemar membaca, peduli lingkungan, peduli sosial, dan tanggung jawab. (Kemendiknas, 2010). Ke delapan belas nilai karakter di atas tersebut menjadi landasan penting dalam memahami karakter bangsa. Karena saat ini nilai karakter tersebut semakin terdegradasi oleh nilai-nilai karakter yang lain, salah satunya diakibatkan adanya kehidupan hedonisme dan modernisme di masyarakat global.

Maka menjadi benar adanya kemunculan pendidikan karakter ini dilatar belakangi oleh beberapa keadaan, yakni 1). Dunia terus mengalami perubahan. Di tengah perubahan tersebut, penegakan disiplin dan aturan yang ada tampak melemah, sehingga terjadi ketidakjelasan mana yang salah dan mana yang benar. 2). Meningkatnya sikap egoisme dan pelanggaran terhadap hak-hak orang dengan melakukan kekerasan. Sehingga hal tersebut memicu perkelahian antar individu/kelompok. 3). Perubahan sikap anak. Alasan ini menjadi penting karena adanya banyak keluhan orang tua terhadap interaksi mereka dengan anaknya, seperti anak lebih pendiam di rumah, malas bersekolah, tidak mau belajar secara rajin, menyontek, angkuh, mem-bully teman, dan seterusnya. (Djaenuddin, 2009).

Oleh karenanya, untuk mengkonstruksi nilai karakter bangsa, terdapat tiga hal yang harus berlangsung secara terintegrasi, yakni 1). Anak memahami baik dan buruk, mengerti tindakan yang harus dilakukan, mampu memprioritaskan hal yang baik. 2). Anak memiliki kecintaan terhadap kebaikan dan membenci keburukan. Kecintaan ini merupakan obor semangat untuk terus berbuat baik. 3). Anak mampu melakukan kebaikan dan terbiasa melakukannya. (Saliman, 2011). Hal tersebut merupakan realitas bahwa membentuk nilai karakter dalam diri anak adalah tugas berat sehingga harus diemban tidak hanya bagi civitas akademika, tetapi juga harus 
terintegrasi mulai dari lingkungan sekolah, lingkungan keluarga, dan lingkungan sosial masyarakat yang mengelilinginya.

Sedangkan dalam konteks teori struktur fungsional, dasar dan gagasan utama teori ini memandang realitas sosial sebagai hubungan sistem, yakni: sistem masyarakat, yang berada dalam keseimbangan, yakni kesatuan yang terdiri dari bagian-bagian yang saling tergantung, sehingga perubahan satu bagian dipandang menyebabkan perubahan lain dari sistem. Menurut Khoiruddin Nasution, maksud teori struktur fungsional adalah teori yang mengasumsikan masyarakat sebagai organisme ekologi yang mengalami pertumbuhan. Semakin besar pertumbuhan terjadi, semakin kompleks pula masalah yang dihadapi. Pada gilirannya akan terbentuk kelompok-kelompok atau bagian-bagian mempunyai fungsi sendiri pula, yang boleh jadi satu bagian mempunyai fungsi yang berbeda dengan yang lainnya. (Khoiruddin, 2016: 229).

Adapun prinsip-prinsip pokok struktur fungsional dapat dijelaskan sebagai berikut:

a. Masyarakat merupakan sistem yang kompleks yang terdiri dari bagian-bagian yang saling berhubungan dan saling tergantung, dan setiap bagian tersebut berpengaruh secara signifikan terhadap bagian-bagian lainnya.

b. Setiap bagian dari masyarakat eksis karena bagian tersebut memiliki fungsi penting dalam memelihara eksistensi dan stabilitas masyarakat secara keseluruhan, karena itu eksistensi satu bagian tertentu dari masyarakat dapat diterangkan apabila fungsinya bagi masyarakat sebagai keseluruhan dapat diidentifikasi.

c. Semua masyarakat mempunyai mekanisme untuk mengintegrasikan dirinya, yaitu mekanisme yang dapat merekatkannya menjadi satu. Adapun salah satu bagian penting dari mekanisme ini adalah komitmen para anggota masyarakat kepada serangkaian kepercayaan dan nilai yang sama.

d. Masyarakat cenderung mengarah kepada suatu keadaan homeostatis, dan gangguan pada salah satu bagiannya cenderung menimbulkan penyesuaian pada bagian lain agar tercapai harmoni dan stabilitas.

e. Perubahan sosial merupakan kejadian yang tidak biasa dalam masyarakat, tetapi jika itu terjadi, maka perubahan pada umumnya akan membawa kepada konsekwensi-konsekwensi yang menguntungkan masyarakat secara keseluruhan. (Sanderson, 2000: 9).

\section{METODE}

Penelitian ini merupakan penelitian kualitatif (qualitative research) yang bersifat naturalistik, yakni memfokuskan pada penanaman pendidikan karakter dalam struktur sosial keluarga desa di Yogyakarta. Adapun strategi yang dipakai adalah dengan menggunakan studi kasus. (Nawawi, 2003:1).

Penelitian ini memusatkan diri pada keluarga desa di beberapa daerah di Kecamatan Piyungan Bantul Yogyakarta dan sekitarnya dengan mengkajinya secara komprehensif sebagai suatu kasus. Data studi kasus dapat diperoleh dari semua pihak yang memiliki relevansi kuat terhadap objek yang diteliti. Adapun objek yang diteliti adalah keluarga di beberapa desa di Piyungan.

Data diperoleh dari penelitian ini melalui wawancara dengan beberapa keluarga, baik keluarga dari penduduk asli daerah, maupun keluarga dari pendatang dari daerah lain yang telah menetap lama. Data juga diperoleh melalui observasi di beberapa daerah untuk memahami bagaimana realitas keluarga desa di Piyungan. Tidak hanya itu, data juga diambil melalui berbagai dokumentasi yang masih ada kaitan dengan objek penelitian. 


\section{HASIL DAN PEMBAHASAN}

Keluarga merupakan unit universal yang memiliki peraturan sendiri yang harus ditaati dan aturan tersebut memiliki fungsi masing-masing, seperti peraturan bergaul anak untuk berinteraksi sosial, belajar lebih mandiri, dan seterusnya. Tanpa aturan yang dijalankan oleh unit keluarga, maka unit keluarga tersebut tidak memiliki arti (meaning) yang dapat menghasilkan suatu kebahagiaan. Begitu juga yang terjadi dalam keluarga desa di Yogyakarta, anak sejak dini diberikan aturan ketat untuk belajar bersosialisasi dengan njawani (sesuai dengan budaya Jawa Yogyakarta). Fungsi dari njawani ini tidak hanya memahami bahasa Jawa, tetapi lebih dari itu. Ia harus berfungsi menjalankan etika, budaya, dan agama yang telah mengakar di masyarakat sejak turun temurun.

Untuk melaksanakan fungsinya secara optimal, yakni meningkatkan derajat "fungsionalitas"nya, keluarga desa Yogyakarta mempunyai struktur tertentu. Struktur adalah pengaturan peran di mana sebuah sistem sosial tersusun. Istilah "sistem sosial" sangat krusial bagi fungsionalis yang merupakan konstruk lebih luas di bawah struktur sehingga terjadi pengaturan peran. Dari sini lah letak bagaimana struktur sosial mampu memberikan ruang peran keluarga desa untuk menanamkan pendidikan karakter anakanaknya.

Bagi masyarakat Jawa, pendidikan karakter dapat dipahami melalui pituduh (wejangan). Dan pituduh tersebut tidak akan bermanfaat jika hanya diucapkan, tanpa dilaksanakan. Hal ini sesuai dengan adigium "gedhang awoh pakel, ngomong gampang nglakoni angel" (ibarat buah pisang berbuah mangga, bicara mudah tapi menjalankannya susah). Tentu bagi keluarga Jawa hal tersebut tidak mereka inginkan. (Idrus, 2012: 122).
Maka dari itu, untuk memudahkan uraian tentang penanaman pendidikan karakter anak dalam konteks struktur sosial keluarga desa di Yogyakarta, secara lebih sistematis peneliti akan menguraikan dua aspek penting, di antaranya:

\section{A. Aspek Struktural dalam Keluarga Desa di Yogyakarta}

Struktur dalam keluarga desa di Yogyakarta telah menjadikan institusi keluarga sebagai sistem kesatuan. Yakni anggota keluarga menyadari bahwa antara individu satu dengan yang lain memiliki perbedaan, tetapi saling berhubungan dan saling ada ketergantungan. Sehingga setiap individu yang berbeda tersebut memiliki pengaruh terhadap individu lainnya

Maka setidaknya terdapat tiga elemen utama dalam struktur keluarga desa Yogyakarta yang saling terkait satu sama lainnya, yaitu:

1. Status Sosial

Status sosial yang dimaksud adalah bagaimana figur-figur dalam keluarga desa mampu menjalankan statusnya masingmasing. Kita bisa melihat seorang bapak mengajarkan nilai tanggung jawab, kerja keras, dan bersikap demokratis, dengan berstatus memimpin keluarga dan bekerja keras mencari nafkah utama. Sedangkan seorang ibu mengajarkan nilai kasih sayang dan peduli dengan menjalankan statusnya sebagai pembantu bapak untuk ikut andil dalam mencari nafkah tambahan keluarga.

Dalam keluarga desa Yogyakarta, anak yang masih balita dititipkan tetangga sebagai pengasuh anak atau diasuh sendiri oleh neneknya, sedangkan anak usia sekolah bersekolah dari pagi sampai siang dan sorenya bermain bersama dengan teman di sekeliling rumahnya. Adanya kesadaran dalam status sosial ini membuat keluarga desa di Yogyakarta tetap harmonis dan humanis. 


\section{Fungsi Sosial}

Peran orang tua dalam keluarga desa di Yogyakarta adalah peran instrumental yang dilakukan oleh suami atau bapak, dan peran emosional yang dipegang oleh figur istri atau ibu. Kedua peran ini berfungsi pemberi cinta, kelembutan, kepedulian, dan nilai-nilai karakter lainnya. Fungsi suami/bapak sebagai pemimpin harus bertanggung jawab atas semua dinamika dalam keluarga, sedangkan peran istri/ibu sebagai 'manager' yang harus mengatur urusan dalam rumah tangga. Di sisi lain, peran ibu dalam keluarga desa juga sebagai 'guru' yang harus mendidik, mengayomi, memberikan kasih sayang, serta bertanggung jawab penuh terhadap kesehatan kepada anak-anaknya.

Dalam keluarga petani, misalnya, menjelang pagi Shubuh bangun bersama dan sholat berjama'ah di masjid. Setelah itu, suami menyiapkan alat-alat pertanian dan istri memasak di dapur. Sekitar jam enam pagi, suami pergi ke sawah, istri mempersiapkan kebutuhan anak-anak untuk sekolah (termasuk sarapan). Setelah anak berangkat sekolah, istri membereskan urusan rumah kemudian menyusul suami ke sawah dengan membawa bekal untuk minum, kue seadanya dan makan siang. Sebelum waktu Dhuhur mereka pulang, untuk menjalan ibadah sholat dan istirahat tidur siang. Setelah itu suami kembali ke sawah sampai sore hari. Hal ini menjadi rutinitas bagi keluarga petani di keluarga desa di Piyungan Yogyakarta, pemandangan seperti ini sering juga kita temui di daerah-daerah lain di Yogyakarta.

Jika terjadi penyimpangan atau tumpang tindih fungsi antara satu dengan yang lainnya, maka sistem keutuhan keluarga desa ini akan mengalami ketidak-seimbangan. Maka dalam keluarga desa di Yogyakarta pada umumya antara suami dan istri sama-sama mencari nafkah sebagaimana penjelasan di atas, tetapi keduanya masih memegang fungsi sosial dalam keluarga mereka masing-masing. Mereka dalam keseharian memiliki mekanisme tersendiri yang bisa mengintegrasikan masing-masing anggota keluarganya, sehingga terjadi satu kesatuan yang utuh yang saling berfungsi. Di sinilah teori struktur fungsional dapat dilihat dan dipahami secara jelas, karena teori ini berupaya menjelaskan bagaimana sistem itu senantiasa berfungsi sesuai peran yang ada dalam masyarakat, yang dalam hal ini keluarga desa di Yogyakarta.

\section{Norma Sosial}

Norma sosial di sini adalah sebuah peraturan yang menggambarkan bagaimana seseorang bertingkah laku dalam kehidupan sosialnya, seperti halnya fungsi sosial. Norma sosial sendiri juga berarti kebiasaan umum yang menjadi patokan perilaku pada suatu kelompok masyarakat dan batasan wilayah tertentu. Di dalam keluarga desa di Piyungan Bantul Yogyakarta, misalnya, keluarga satu dengan yang lain mempunyai karakteristik yang berbeda berupa diferensiasi peran, dan struktur organisasi yang jelas.

Norma sosial yang sering dijadikan patokan di masyarakat desa adalah "Dadi wong Jowo kui kudu njawani. Ojo nglakoni perkoro simg saru." Dalam artian, menjadi orang (Jawa) harus mengetahui (sekaligus menyadari) norma-norma masyarakat Jawa pada umumnya. Orang Jawa harus menghindari sesuatu yang dilarang dan dianggap tidak pantas dalam budaya Jawa. Norma ini akhirnya menjadi kebiasaan masyarakat di Yogyakarta, sehingga tak jarang anak-anak di dalam lingkungan keluarga dididik untuk tidak melalukan 
sesuatu yang "saru” (hal-hal yang tidak pantas dilakukan oleh anak dalam interaksi sosial), seperti memanggil kakaknya dengan kata "koe" (kamu), yang semestinya pakai bahasa yang lebih halus (bisa dengan menyebut nama kakak atau memanggil dengan kata "sampean/panjenengan").

Bahkan berdasarkan hasil penelitian, menyebutkan beberapa nilai pendidikan yang sejak kecil telah dikenalkan para orangtua kepada anak-anaknya dalam keluarga di Jawa, di antaranya: sabar, jujur, pengendalian diri, budi luhur, prihatin, rukun, hormat, manut, murah hati, menghindari permusuhan, tepo saliro, empati, sopan santun, rela, nerimo, pengabdian, dan eling. (Idrus, 2004). Nilainilai tersebut sudah menjadi norma yang terus dipertahankan di masyarakat Jawa, termasuk pada keluarga desa di Yogyakarta.

\section{B. Aspek Fungsional dalam Keluarga Desa di Yogyakarta}

Struktur keluarga desa di Yogyakarta memiliki karakteristik tersendiri, khususnya dalam mendidik anak-anaknya. Di sini akan dijelaskan bagaimana keluarga desa di Yogyakarta dapat dilihat dari aspek fungsionalnya, yakni dijadikan sebagai sistem sosial yang berfungsi, antara lain:

\section{Diferensiasi Sosial}

Dari serangkaian tugas dan aktivitas yang harus dilakukan dalam keluarga desa di Yogyakarta, masing-masing anggota keluarga dituntut untuk memahami alokasi peran untuk setiap aktor di dalamnya. Keseimbangan dan keselarasan dari berbagai aktor di keluarga memberikan penanganan yang baik. Seorang suami dan istri harus menjalin interaksi sosial yang baik satu sama lain. Begitu juga anakanak harus menjalin hubungan sosial di dalam lingkup keluarga dengan menghargai saudarasaudaranya. Seorang adik harus menghormati kakak. Seorang kakak juga harus mengayomi adiknya. Alokasi peran masing-masing ini menjadikan diferensiasi sosial terjalin dengan seimbang.

Tidak hanya itu, keluarga desa di Yogyakarta masih memegang penuh nilainilai budaya Jawa. Salah satu contoh kecilnya adalah mempertahankan pendidikan bahasa Jawa halus khas Yogyakarta kepada anakanaknya. Hal ini tentu menjadi nilai positif bagi penanaman karakter anak, karena di samping untuk menjaga keutuhan budaya, juga untuk memperkuat semangat kesetiaan terhadap nilai-nilai luhur karakter bangsa.

\section{Alokasi Solidaritas}

Melihat hubungan keluarga desa di Yogyakarta, alokasi waktu dalam konteks solidaritas dari masing-masing keluarga dilakukan secara total. Sehingga distribusi relasi antar anggota keluarga tetap dipenuhi rasa cinta, kekuatan untuk saling berbagi kebahagiaan, dan intensitas hubungan yang terjaga dengan baik.

Alokasi solidaritas lainnya adalah kekuatan gotong-royong masyarakat desa yang masih dipertahankan. Tidak hanya ruang lingkup masyarakat secara luas, solidaritas gotong-royong juga diperlihatkan keluarga desa di waktu hari libur. Banyak ditemui keluarga mengisi waktu libur sekolah (hari Minggu) dimanfaatkan untuk kerja membersihkan pekarangan rumah. Suami melakukan hal-hal yang dirasa berat, seperti menebang pohon, dan seterusnya. Sementara anaknya melakukan pekerjaan yang ringan, seperti menyapu, membersihkan rumput di halaman dan seterusnya. Sedangkan istri di samping ikut terlibat pekerjaan, ia juga berperan menyiapkan hidangan, baik berupa minuman teh hangat, maupun kue camilan. Alokasi solidaritas ini menjadi simbol bahwa memanfaatkan waktu 
untuk keluarga merupakan faktor penting dalam menanamkan pendidikan karakter dalam diri anak. Anak tidak hanya diajarkan secara teoritis, tetapi juga diajarkan secara praktis. Sehingga keterlibatan anak dalam berbagai aktivitas luang keluarga menjadi nilai keharmonisan tersendiri.

\section{Alokasi Politik}

Distribusi kekuasaan suami dalam keluarga memiliki bertanggung jawab atas setiap tindakan anggota keluarganya. Tidak hanya itu, dalam hal tertentu istri juga memiliki tanggung jawab serupa dengan suami. Istri dalam keluarga desa harus tunduk patuh terhadap suami. Bahkan dalam filosofi Jawa kuno, seorang istri itu seharusnya berperan penuh dalam tiga M (Masak/memasak, Macak/berhias diri, dan Manak/melahirkan). Jika dilihat dalam konteks positif filosofi di balik itu, istri dalam keluarga Jawa harus secara penuh menghargai suami sebagai pemimpin tertinggi dalam keluarga. Begitu juga suami harus juga mengayomi istri dan anak-anaknya secara total.

Anak-anak dididik harus mentaati otoritas bapak, ibu, dan orang-orang yang lebih tua darinya. Banyak kaidah aturan keluarga desa di Yogyakarta yang harus dipenuhi seorang anak, sehingga nilai dan keyakinan politik dari kedua orang tua dapat terlaksana. Di beberapa keluarga desa yang memiliki cukup pendidikan, banyak ditemui bagaimana pembuatan keputusan dalam keluarga selalu melibatkan anak-anaknya. Tentu hal ini dapat meningkatkan kompetensi dan aktualisasi diri dalam politik anak serta dapat memberikan kecakapan tersendiri untuk melakukan interaksi politik dalam lingkup keluarga.

Dari hasil observasi peneliti di beberapa daerah di Yogyakarta, suami dan istri di dalam keluarga desa selalu terlibat dalam urusan rumah tangganya. Bahkan hal ini sangat baik untuk percontohan pendidikan karakter anak dalam lingkup keluarga di daerah-daerah lainnya. Karena adanya peran suami dan istri sama-sama terlibat dalam memperjuangkan kehidupan keluarganya, maka akan lebih mampu mengatasi konflik-konflik yang terjadi dalam urusan rumah tangga tanpa merugikan salah satu pihak. Hal ini juga akan mengurangi adanya stress pada pasangan ganda (baca: keduanya sama-sama mencari nafkah) akibat menumpuknya tugas-tugas dalam rumah tangga.

Peneliti melihat di beberapa kasus dalam keluarga desa di Piyungan Bantul, keterlibatan suami dalam kegiatan rumah tangga menjadi sesuatu yang lumrah terjadi, terutama dalam hal pengasuhan anak (seperti merawat dan mendidik anak), membersihkan dan merawat rumah, menyiapkan makanan, belanja ke pasar, mencuci baju, menyiapkan keperluan pribadi lainnya. Dalam konteks ini, fungsi sosial dalam keluarga desa terjalin secara menarik. Hal ini tentu diharapkan untuk keharmonisan keluarga di waktu-waktu tertentu. Dalam penelitian Gronselth dengan meneliti 16 pasangan suami-istri yang bekerja, menemukan bahwa dengan ayah dan ibu yang sama-sama mengambil bagian dalam mengasuh anak, kaum ayah merasa lebih baik dan terbuka dengan anak-anaknya. Sehingga anak-anak tumbuh dengan kemampuan diri lebih tinggi serta keyakinan diri lebih besar, cenderung lebih matang dan dapat bergaul, serta mampu menghadapi berbagai masalah. Perkembangan berbahasa pada anak-anak ini juga menjadi lebih tinggi. Dilaporkan bahwa anak-anak tersebut mendapat nilai pedagogis yang tinggi. Hal ini berkaitan erat dengan rangsangan-rangsangan yang diberikan ayah dalam membantu perkembangan kognitif anak. (Sri Supriyantini, 2002). 
Secara khusus, peranan suami dalam kegiatan rumah tangga menjadi hal yang penting karena akan membantu menyelamatkan istri dari kelebihan peran, yakni peran dalam keluarga dan peran dalam masyarakat. Dengan demikian, istri merasa dihargai dan suasana keluarga akan lebih baik, serta penanaman pendidikan karakter anak dalam nilai-nilai luhur Jawa akan senantiasa tercipta. Jika suami ikut terlibat dalam kegiatan rumah tangga, minimal istri akan merasa terbantu, karena adanya perhatian suami.

Semua itu tentu merupakan bagian dari perubahan sosial yang ada dalam keluarga desa di Yogyakarta, yang (mungkin) dahulu belum kita temui. Dalam konteks lain, kejadian tersebut merupakan kejadian yang tidak biasa dalam masyarakat secara umum. Maka jika hal tersebut telah terjadi, maka perubahan tersebut akan membawa kepada konsekuensi logis yang menguntungkan masyarakat secara keseluruhan, dan memberikan nilai lebih bagi keluarga desa di Yogyakarta itu sendiri. Maka dari itu, hal tersebut akan tercipta struktur fungsional, karena menjadikan fungsi perkawinan dengan harapan rumah tangga harmonis tercapai secara maksimal.

\section{SIMPULAN}

Memahami struktur sosial keluarga desa di Yogyakarta yang berimplikasi pada penanaman pendidikan karakter anak, sejak dini anak telah diberikan pendidikan njawani, yakni pendidikan yang tidak hanya berfungsi memahami bahasa Jawa, tetapi juga harus menjalankan etika, budaya, dan agama yang telah mengakar di masyarakat Jawa Yogyakarta.

Dalam mengoptimalkan fungsi sosialnya, keluarga desa di Yogyakarta mempunyai struktur tertentu, di mana sebuah sistem sosial tersusun sehingga antara masing-masing anggota keluarga terjadi pengaturan peran satu sama lain. Di sini, struktur sosial mampu memberi ruang dalam menanamkan pendidikan karakter pada anak. Untuk itu, diperlukan pemahaman secara utuh dengan menyadari dua aspek penting dalam keluarga desa di Yogyakarta, yakni aspek struktural dan aspek fungsional. Kedua aspek ini akan memperlihatkan bagaimana perubahan keluarga desa saat ini. Perubahan tersebut membawa konsekuensi yang bisa memberikan keuntungan tersendiri bagi masyarakat dan keluarga desa itu sendiri.

\section{DAFTAR PUSTAKA}

Djaenuddin. 2009. Program Pendidikan Karakter di Lingkungan. Tabloid Penabur Jakarta. No. 25 Thn VII Edisi Maret-April.

Hadari, Nawawi. 2003. Metode Penelitian Bidang Sosial. Yogyakarta: UGM Press.

https://id.wikipedia.org/

Idrus, M. 2004. Kepercayaan Eksistensial Remaja Jawa. Disertasi. Yogyakarta: Fakultas Psikologi Universitas Gadjah Mada.

Idrus, Muhammad. 2012. Pendidikan Karakter pada Keluarga Jawa. Jurnal Pendidikan Karakter. Tahun II. Nomor 2.

Kemendiknas. 2010. Bahan Pelatihan Penguatan Metodologi Pembelajaran Berdasarkan Nilai-Nilai Budaya untuk Membentuk Daya Saing dan Karakter Bangsa: Pengembangan Pendidikan Budaya dan Karakter Bangsa. Jakarta: Badan Penelitian dan Pengembangan Kurikulum.

Moleong, Lexy J. 2001. Metodologi Penelitian Kualitatif. Bandung: Rosdakarya.

Nasution, Khoiruddin. 2016. Pengantar Studi Islam. Jakarta: Rajawali Press.

Soekanto, Soerjono. 2005. Sosiologi Suatu Pengantar. Jakarta: PT. Raja Grafindo Persada.

Sabeni, Beni Ahmad. 2012. Pengantar Antropologi. Bandung: Pustaka Setia. 
523 Penanaman Pendidikan Karakter Anak Dalam Stuktur Sosial Keluarga Desa Di Yogyakarta Ahmad Shofiyuddin Ichsan, Samsudin

Saliman. 2011. Membangun Karakrer Bangsa

Melalui Bahasa Simbolik Jawa.

Yogyakarta: Universitas Negeri

Yogyakarta.

Sanderson, Stephen K. 2000. Sociological Worlds: Comparative and Historical Readings on Society. Chicago: Fitsroy Dearborn Publisher.

Supriyantini, Sri. 2002. Hubungan antara Peran Gender dengan Keterlibatan Suami dalam Kegiatan Rumah Tangga. Sumut: Fakultas Kedokteran Program Studi Psikologi, Universitas Sumatra Utara. 